\section{Birmingham Hospitals Centre}

THE annual degree congregation at the University of Birmingham on July 2 marked the completion of the new medical school and the Birmingham Hospitals Centre by the conferment of honorary degrees on three laymen whose benefactions and services have been outstanding-Sir Bertram Ford, Viscount Nuffield and Mr. Harry Vincent ; and three representatives of the medical profession: Dr. Robert Hutchison, Sir Edward Mellanby, and Sir Cuthbert Wallace. At a luncheon afterwards, the Guild of Graduates entertained the honorary graduates. The chancellor, Viscount Cecil, in proposing the toast of the new graduates, referring to Lord Nuffield, said that he was the successor of a very long line of splendid citizens. They knew he stood for progress, not only physically but also intellectually and morally. When he made his splendid gifts he considered most carefully how they would be for the greatest advantage of the people he was anxious to benefit. "In the case of his gift to our department of Physics, I think he felt that he was not only helping the University of Birmingham or the science of physics, but indirectly, in a most important degree, giving assistance to the industry and intellectual advance of the whole country."

Dr. RoBert Hutchison congratulated the City and the University on the great work that had been carried out in forming the Hospitals Centre, and expressed his belief that the example set by Birmingham in the concentration of medical resources in one quarter will be widely followed in other cities. Sir Edward Mellanby said that the fight against disease has as its limiting factor lack of knowledge. The present year has been a particularly good one from the point of view of discovery. One of the greatest discoveries of the time has come from a Birmingham hospital, Dudley Road, namely, the curative properties of the new drug M. and B. 693, which gives us considerable control over that terrible disease, pneumonia. "The greatest part of research is the prevention of disease. This is going on side by side with these other discoveries. This other type of work, the clearing out of disease, is becoming more and more powerful, and I have no hesitation in saying that in fifty years your great hospital here will be put to other uses than it is to-day. It may, of course, be full of motor accidents; or it may be full of very old people whiling away their last years of life in peace and happiness ; or it may be occupied by the University for ordinary teaching. At any rate it is going to be quite different, because the rate of progress is so rapid."

\section{National Museum for Southern Rhodesia}

IT is reported that a national museum for Southern Rhodesia is to be instituted in the neighbourhood of the Zimbabwe ruins. The trustees of the Southern Rhodesia Sweepstake Lotteries are to be asked to bear the cost of the building, but in the event of their being unable to provide the amount required, the sum necessary will be raised by the Government from its funds. It is to be presumed from the location of the site that the museum, though general in character as a national museum should be, will devote special attention to the antiquities of the adjacent Zimbabwe area and the culture of its native inhabitants past and present, in which the Governments of South Africa have already evinced their interest by the assistance they have given to the archæological investigations undertaken by the joint universities committee for archæological research. Although the situation of the museum may seem somewhat remote from any academic centre, this will scarcely prove a deterrent to the serious student, who will appreciate the advantage of studying the culture of the Zimbabwe in its natural setting, more especially if it should prove possible to get together a really representative selection of the antiquities which have been found in the ruins from time to time. The proximity of the museum to the Victoria Falls, as well as to the ruins, should ensure that it does not suffer from lack of visitors. As an illustration of the most remarkable feature in South Africa's cultural history, such a collection should have the highest educational value.

\section{Prehistoric Research in Great Britain}

The Prehistoric Society (formerly the Prehistoric Society of East Anglia), has recently established a research fund with the object of undertaking the excavation of a series of key sites in Britain in order to develop our knowledge of the prehistory of the country. Of the competence of the Society to undertake the direction and administration of such a fund there can be no question. Its membership of seven hundred includes most of those prominent in the study of prehistoric archæology both in Great Britain and abroad; and among them are those who have been mainly responsible for recent rapid advances in our systematized knowledge of the mesolithic, neolithic and iron age periods in Britain. The advantages which will accrue from a research fund under the control of the Society are patent. The facility for systematic planning of research, combined with flexibility in the application of effort, both of man-power and of financial resources, will make it possible to add effectively to the sum of organized knowledge in those periods and departments of British prehistory where it may be needed most from time to time. A beginning is to be made in this season, when it is proposed to excavate an iron age village site near Britford, one mile south of Salisbury Cathedral. This site is believed to belong to the earlier part of the period 500-100 B.c. The village enclosure was dug out of the chalk by its inhabitants, and its form is known in some detail, but only from photographs taken at a height of $2,000 \mathrm{ft}$. in air survey, which revealed the existence of the site. The object of the excavation will not be to lay bare the site as such, so much as to throw light on the mode of life and organization of a settlement of small farmers and stock raisers of the period. The Society appeals for contributions to the research fund, which should be addressed to the Honorary Secretary, Mr. C. W. Phillips, Selwyn College, Cambridge. 